\title{
Energy and Economic Budgeting of Pigeonpea Genotypes (Cajanus cajan L.) at Various Sowing Dates
}

\author{
Dasharath Prasad, Vijay Prakash, S.K. Bairwa, P.S. Chauhan
}

10.18805/LR-4670

\begin{abstract}
Background: Early duration pigeonpea genotypes a boon as the crop needs a very little amount of inputs, survives well even under available water conditions because of its Bio-tillage in nature. There are many causes of low productivity of pigeonpea, using long duration genotypes, using convention varieties, non monitored input like sowing date and management practice and short duration genotypes play a very important role in productivity as well as production in Rajasthan.

Methods: A two-year field experiment was conducted at the Agricultural Research Station, Sriganganagar Rajasthan, during the Kharif season of the year 2018 and 2019. The experiment is laidout with a split plot design with thrice replication, in the main plot four dates of sowing allotted viz: $D_{1}: 25^{\text {th }}$ May, $D_{2}: 10^{\text {th }}$ June, $D_{3}: 25^{\text {th }}$ June and $D_{4}: 10^{\text {th }}$ July and in subplot five genotypes allotted viz: $V_{1}$ : UPAS-120, $\mathrm{V}_{2}$ : ASJ-105, $\mathrm{V}_{3}$ : Pant- 291, $\mathrm{V}_{4}$ : PUSA- 992, $\mathrm{V}_{5}$ : ICPL- 88039.

Result: Field experiments resulted, the Sowing date $D_{2}: 10^{\text {th }}$ June $\left(1451 \mathrm{~kg} \mathrm{ha}^{-1}\right)$, is best suitable as compared to others in terms of yields, its attributes and B:C ratio both the years. In the short duration varieties $\mathrm{V}_{4}$ : PUSA-992 (1586 kg ha ${ }^{-1}$ ) superior to others. In respect of different sowings dates the energy budgeting viz: energy use efficiency varies from $D_{1}: 25^{\text {th }}$ May $(9.80)$ and $(5.99)$ to $D_{4}: 10^{\text {th }}$ July (8.14) and (4.95), energy productivity $\left(\mathrm{kg} \mathrm{MJ}^{-1}\right)$ varies from $\mathrm{D}_{1}: 25^{\text {th }}$ May $(0.164)$ and $(0.104)$ to $\mathrm{D}_{4}: 10^{\text {th }}$ July $(0.126)$ and $(0.078)$ in both the years. In respective of genotypes the higher energy use efficiency found in $\mathrm{V}_{4}$ : PUSA-992 (10.34), (6.56), energy productivity in $\mathrm{V}_{4}$ : PUSA-992 $\left(0.171 \mathrm{~kg} \mathrm{MJ}^{-1}\right),\left(0.111 \mathrm{~kg} \mathrm{MJ}^{-1}\right)$ which was superior with others in all aspect in both the years respectively.
\end{abstract}

Key words: Date of sowing, Energy, Economic, Genotypes, Pigeonpea, Yield.

\section{INTRODUCTION}

Pigeonpea (Cajanus cajan L.) is the second most important pulse crop next only to chickpea in India. From the nutritional point of view, vegetable proteins play an important role especially in rural areas, which house over $70 \%$ of the population in Rajasthan. Among the pulses pigeonpea is the second most important Kharif grain legume after chickpea in India and is grown predominantly under rainfed conditions. The kernels are nutritionally rich containing 20$22 \%$ protein. Its cultivation would be able to provide $40-60$ $\mathrm{kg} \mathrm{N} /$ ha to the subsequently grown crop (Sarkar et a/2020). It is known to improve soil nutrition through nitrogen fixation and physical structure by adding organic matter from fallen leaf mass.

In the zone $1 \mathrm{~b}$ under irrigated area major crops are cotton, cluster bean and some extent green gram during kharif (rainy) season. The introduction of pigeonpea in this canal irrigated area may be useful to farmers as follows, crop diversification by introducing new high yielding varieties and short duration pigeonpea varieties in the zone. Sowing time, a non-monetary input, has considerable influence on the growth and yield of pigeonpea crop. In addition, genotypes may vary in productivity (Umesh et al. 2013). However, with the changing climate, the optimum time of sowing may vary. Furthermore, when the crop is sown during the first fortnight of June, many times the maturity of the crop is delayed (Ram et al. 2011).

Energy use and output production knowledge in different cropping systems is needed to investigate how to
Department of Agronomy, Agricultural Research Station, Sriganganagar-335 001, Rajasthan, India.

Corresponding Author: Dasharath Prasad, Department of Agronomy, Agricultural Research Station, Sriganganagar-335 001, Rajasthan, India. Email: dashrath.sagar@gmail.com

How to cite this article: Prasad, D., Prakash, V., Bairwa, S.K. and Chauhan, P.S. (2021). Energy and Economic Budgeting of Pigeonpea Genotypes (Cajanus cajan L.) at Various Sowing Dates. Legume Research. DOI: 10.18805/LR-4670.

Submitted: 21-05-2021 Accepted: 27-07-2021 Online: 21-08-2021

improve EUE while maintaining crop production to free up land for energy crops. Agriculture in a ways an energy conversion industry. Energy use in agricultural production has been increasing faster than that of in many other sectors of the world economy because agricultural production has become more mechanized and commercial fertilizers dependent by the Shilpha et al., (2018).

\section{MATERIALS AND METHODS} Field experiment

The two-year field experiment was conducted during the Kharif season of the year 2018 and 2019 at Agricultural Research Station, Sriganganagar, Rajasthan, (S.K. Rajasthan Agricultural University Bikaner) on pigeonpea to find out the suitable date of sowing and suitable early maturing varieties of pigeonpea for Zone $\mathrm{lb}$ of Rajasthan India. It is a canal irrigated area located between $28.4^{\circ}$ to 
$30.6^{\circ}$ North latitude and $72.3^{\circ}$ to $75.30^{\circ}$ East longitude under North-Western Plain Zone (1b). The soil of the experimental site was sandy loam in texture, low in organic carbon $(0.19 \%)$, medium in available $\mathrm{P}_{2} \mathrm{O}_{5}(33 \mathrm{~kg} / \mathrm{ha})$ and high in available $\mathrm{K}_{2} \mathrm{O}(330 \mathrm{~kg} / \mathrm{ha})$. The $\mathrm{pH}(1: 2)$ and $\mathrm{EC} \mathrm{(1:2)} \mathrm{of} \mathrm{the}$ soil were 8.1 and $0.20 \mathrm{dS} / \mathrm{m}$, respectively. A uniform basal dose of $20 \mathrm{~kg} \mathrm{~N} / \mathrm{ha}+40 \mathrm{~kg} \mathrm{P} \mathrm{O}_{5} /$ ha was applied at the time of sowing. The experiment is laid out with a split-plot design with thrice replication, in the main plot four dates of sowing allotted viz: $D_{1}: 25^{\text {th }}$ May, $D_{2}: 10^{\text {th }}$ June, $D_{3}: 25^{\text {th }}$ June and $D_{4}$ : $10^{\text {th }}$ July and in subplot five genotypes allotted viz: $V_{1}$ : UPAS120, $V_{2}$ : ASJ-105, $V_{3}$ : Pant- 291, $V_{4}$ : PUSA- 992, $V_{5}$ : ICPL88039 . The plot size $3 \times 6 \mathrm{~m}$, crop geometry of $50 \mathrm{~cm} \times 30$ $\mathrm{cm}$ were maintained.

\section{Energetic budgeting}

Based on the energy inputs and output, energy use efficiency, energy productivity in physical terms and economic terms (Mittal and Dhawan 1989; Shilpha et al. 2018) were calculated.

(1) Energy balance $\left(\mathrm{MJ} \mathrm{ha}^{-1}\right)=$

Energy output (MJ / ha) - Energy input (MJ / ha)

(2) Energy use efficiency=

$$
\frac{\text { Energy output }\left(\frac{\mathrm{MJ}}{\mathrm{ha}}\right)}{\text { Energy input }\left(\frac{\mathrm{MJ}}{\mathrm{ha}}\right)}
$$

(3) Energy productivity $\left(\mathrm{kg} \mathrm{MJ}^{-1}\right)=\frac{\text { Yield }\left(\frac{\mathrm{kg}}{\mathrm{MJ}}\right)}{\text { Energy input }\left(\frac{\mathrm{MJ}}{\mathrm{ha}}\right)}$

Table 1: Energy input and output equivalent value.

\begin{tabular}{ll}
\hline Particulars & Energy equivalent \\
\hline I. Inputs (Used in Pigeonpea cultivation) & \\
1. Human labor (Women) & $1.57 \mathrm{MJ} /$ Women-hour \\
2. Diesel & $56.31 \mathrm{MJ} / \mathrm{L}$ \\
3. Water & $1.02 \mathrm{MJ} / \mathrm{M}^{3}$ \\
Equipment & \\
4. Tractor & $332 \mathrm{MJ} / \mathrm{hr}$ \\
5. Heavy-duty cultivator & $220 \mathrm{MJ} / \mathrm{ha}$ \\
6. Plough & $180 \mathrm{MJ} / \mathrm{ha}$ \\
7. Disc plough & $149 \mathrm{MJ} / \mathrm{ha}$ \\
Chemical fertilizers and manure & \\
8. Nitrogen & $60.60 \mathrm{MJ} / \mathrm{kg}$ \\
9. Phosphate ( $\left.{ }_{2} \mathrm{O}_{5}\right)$ & $11.1 \mathrm{MJ} / \mathrm{kg}$ \\
10. F.Y.M & $0.30 \mathrm{MJ} / \mathrm{kg}$ (dry mass) \\
Pesticide & \\
11. Insecticide & $237 \mathrm{MJ} / \mathrm{kg}$ a.i. \\
2. Output & \\
12. Pigeonpea (Seed) & $14.07 \mathrm{MJ} / \mathrm{kg}$ \\
13. Residues (Straw) & $19.4 \mathrm{MJ} / \mathrm{kg}$ \\
\hline
\end{tabular}

\section{Economics}

\section{Cost of cultivation}

The expenditure incurred on raising the crop from sowing to harvesting and recorded as cost of cultivation or gross expenditure per hectare ( ${ }^{\prime} \mathrm{ha}^{-1}$ ) for an individual crop of the sequence.

\section{Gross returns}

Total income obtained from seed and stover of the crop was worked out using the MSP expressed as ' $\mathrm{ha}^{-1}$.

\section{Net returns}

The net returns were computed by subtracting the cost of cultivation from gross returns and expressed as ' $\mathrm{ha}^{-1}$.

\section{Returns per rupee invested (B:C ratio)}

This was calculated as follows:

$$
\mathrm{B}: \mathrm{C} \text { ratio }=\frac{\text { Net returns }(' / \mathrm{ha})}{\text { Cost of cultivation }(' / \mathrm{ha})}
$$

\section{Statistical analysis}

Data from experiment were analyzed as two-way ANOVA. All the values presented here represent the mean values of three replications. Significance was tested using F-test at a $5 \%$ level of probability $(P<0.05)$. The standard error of the mean $(\mathrm{SEm}+)$, the critical difference $(\mathrm{CD})$ at $5 \%$ level of probability $(P<0.05)$ were worked out for the study of each parameter by Gomez and Gomez 1984.

\section{RESULTS AND DISCUSSION Yield parametersof pigeonpea Seed per pods}

The number of seed par pods recorded in sowing of $D_{1}: 25^{\text {th }}$ May and gradually decrease in numbers by delayed in sowings from $D_{1}: 25^{\text {th }}$ May (5.17) and (5.64) to $D_{5}: 10^{\text {th }}$ July (4.01) and (4.62) in both the years respectively. In respective of genotypes, the maximum Seed par pods found in genotype $\mathrm{V}_{4}$ : PUSA-992 (5.0), (5.56) and $\mathrm{V}_{5}$ : ICPL-88039 recorded minimum Seed par pods (4.26) and (4.90) respectively in both the years (Table 2 ).

\section{Pods per plants}

The number of pods recorded in maximum in the sowing of $D_{1}: 25^{\text {th }}$ May and gradually decrease in numbers by delayed in sowings from $D_{1}: 25^{\text {th }}$ May (97.55) and (100.54) to $D_{4}$ : $10^{\text {th }}$ July (85.18) and (87.44) in both the years respectively. In respective of genotypes the maximum pods recorded in genotype $\mathrm{V}_{4}$ : PUSA-992 (101.27), (104.17) and $\mathrm{V}_{5}$ : ICPL88039 recorded minimum Seed par pods (84.91) and (87.86) respectively in both the years according to Table 2.

\section{Seed index (g)}

It is the 100-seed weight in gram of respective genotypes. The 100-seed weight recorded in maximum in the early sowing of $D_{1}: 25^{\text {th }}$ May and gradually decrease in numbers by delayed in sowings from $D_{1}: 25^{\text {th }}$ May $(10.85 \mathrm{~g})$ and $(11.13 \mathrm{~g})$ 
to $D_{4}: 10^{\text {th }}$ July $(10.03 \mathrm{~g})$ and $(10.31 \mathrm{~g})$ in both the years respectively. In respective of genotypes, the maximum seed index found in genotype $\mathrm{V}_{4}$ : PUSA-992 $(10.95 \mathrm{~g}),(11.25 \mathrm{~g})$ and $\mathrm{V}_{5}$ : ICPL-88039 recorded minimum Seed index $(9.59 \mathrm{~g})$ and $(9.86 \mathrm{~g})$ respectively in both the years according to Table 2 .

\section{Seed yield and stover yield \\ Seed yield}

It is the economically imported harvest from the crop's respective genotypes. The seed yields recorded higher numerically in the early sowing of $D_{1}: 25^{\text {th }}$ May and gradually decrease by delayed in sowings from $D_{1}: 25^{\text {th }}$ May $(1831 \mathrm{~kg}$ $\left.\mathrm{ha}^{-1}\right)$ and $\left(1179 \mathrm{~kg} \mathrm{ha}^{-1}\right)$ to $\mathrm{D}_{4}: 10^{\text {th }}$ July $\left(1411 \mathrm{~kg} \mathrm{ha}^{-1}\right)$ and $\left(887 \mathrm{~kg} \mathrm{ha}^{-1}\right)$ in both the years respectively. Both sowing of $D_{1}: 25^{\text {th }}$ May and $D_{2}: 10^{\text {th }}$ June are statistically at par in yield, $D_{2}: 10^{\text {th }}$ June $\left(1773 \mathrm{~kg} \mathrm{ha}^{-1}\right)\left(1129 \mathrm{~kg} \mathrm{ha}^{-1}\right)$ is significantly superior with references to $D_{3}: 25^{\text {th }}$ June $\left(1503 \mathrm{~kg} \mathrm{ha}^{-1}\right)(966$ $\left.\mathrm{kg} \mathrm{ha}^{-1}\right)$ and $\mathrm{D}_{4}: 10^{\text {th }}$ July $\left(1411 \mathrm{~kg} \mathrm{ha}^{-1}\right)\left(887 \mathrm{~kg} \mathrm{ha}^{-1}\right)$, in the seed yield percent reduction by $(3.17 \%)(2.24 \%)$ in $\mathrm{D}_{2}: 10^{\text {th }}$ June, by the $(17.91 \%)(18.07 \%)$ in $\mathrm{D}_{3}: 25^{\text {th }}$ June and $(22.94 \%)$ $(24.77 \%)$ in $D_{4}: 10^{\text {th }}$ July recorded as compared with $D_{1}: 25^{\text {th }}$ May sowing dates was in both the years respectively (Table 2), these same work and results reported by Singh et al., (2016) and Ram et al. (2011). In respective of genotypes, the maximum seed yield found in genotype $\mathrm{V}_{4}$ : PUSA-992 (1910 $\left.\mathrm{kg} \mathrm{ha}^{-1}\right),\left(1263 \mathrm{~kg} \mathrm{ha}^{-1}\right)$, which was significantly superior with others followed by $V_{2}$ : ASJ-105 (18.38 $\left.\mathrm{kg} \mathrm{ha}^{-1}\right)\left(1151 \mathrm{~kg} \mathrm{ha}^{-1}\right)$ and $\mathrm{V}_{5}$ : ICPL-88039 recorded minimum Seed yield $(1323 \mathrm{~kg}$ ha-1) $\left(807 \mathrm{~kg} \mathrm{ha}^{-1}\right)$, in the seed yield percent reduction by $(3.77 \%)(8.87 \%)$ in $\mathrm{V}_{2}$ : ASJ-105, in $\mathrm{V}_{3}$ : Pant-291 (16.34\%) $(20.35 \%)$ and maximum loss recorded $\mathrm{V}_{5}$ : ICPL-88039 $(30.73 \%)(36.10 \%)$ recorded as compared to $\mathrm{V}_{4}$ : PUSA-992 in both the year respectively (Table 2). These finding are correlated with Umesh et al.,(2013).

\section{Stover yield}

The stover yields recorded higher numerically in the early sowing of $D_{1}: 25^{\text {th }}$ May and gradually decrease by delayed in sowings from $D_{1}: 25^{\text {th }}$ May $\left(6695 \mathrm{~kg} \mathrm{ha}^{-1}\right)$ and $\left(4112 \mathrm{~kg} \mathrm{ha}^{-1}\right)$ to $\mathrm{D}_{4}: 10^{\text {th }}$ July $\left(5689 \mathrm{~kg} \mathrm{ha}^{-1}\right)$ and $\left(3492 \mathrm{~kg} \mathrm{ha}^{-1}\right)$ in both the years respectively. Both sowing of $D_{1}: 25^{\text {th }}$ May and $D_{2}: 10^{\text {th }}$ June is statistically at par in stover yield, $\mathrm{D}_{2}: 10^{\text {th }}$ June $(6615$ $\left.\mathrm{kg} \mathrm{ha}^{-1}\right)\left(4043 \mathrm{~kg} \mathrm{ha}^{-1}\right)$ is significantly superior over to $D_{3}$ : $25^{\text {th }}$ June (5873 kg ha-1) (3639 $\left.\mathrm{kg} \mathrm{ha}^{-1}\right)$ and $\mathrm{D}_{4}: 10^{\text {th }}$ July, both the years respectively. In respective of genotypes, the maximum stoveryield found in genotype $\mathrm{V}_{4}$ : PUSA-992 (7089 $\left.\mathrm{kg} \mathrm{ha}^{-1}\right),\left(4536 \mathrm{~kg} \mathrm{ha}^{-1}\right)$, which was significantly superior with others followed by $V_{2}$ : ASJ-105 (6866 kg ha-1) (4151 kg ha-1) and $\mathrm{V}_{5}$ : ICPL-88039 recorded minimum stover yield (5265 $\left.\mathrm{kg} \mathrm{ha}^{-1}\right)\left(3124 \mathrm{~kg} \mathrm{ha}^{-1}\right)$, in both the years respectively (Table 2). Similar results were found by Kumar et al.,(2008).

\section{Economics}

\section{Cost of cultivation}

It is the total expenditure to produce as the seeds term known as cost of cultivation. It is found constant in all dates of sowing and genotypes $\left(28.10 \times 10^{3}{ }^{`} \mathrm{ha}^{-1}\right)$ and $\left(28.50 \times 10^{3}{ }^{{ }^{\prime}} \mathrm{ha}^{-1}\right)$ in both years respectively (Table 2 ).

\section{Gross return}

It is the total return from the seed as well as stover yields. It found differ from high to low in early to late sown redgram viz: $\mathrm{D}_{1}: 25^{\text {th }}$ May $\left(77.47 \times 10^{3}{ }^{\text {' }} \mathrm{ha}^{-1}\right)$ and $\left(55.38 \times 10^{3}{ }^{\prime} \mathrm{ha}^{-1}\right)$ to $\mathrm{D}_{4}: 10^{\text {th }}$ July $\left(60.76 \times 10^{3} \mathrm{ha}^{-1}\right)$ and $\left(42.46 \times 10^{3}{ }^{`} \mathrm{ha}^{-1}\right)$ in both the years respectively (Table 3 ). In respective of genotypes the higher gross return found in genotype $\mathrm{V}_{4}$ :

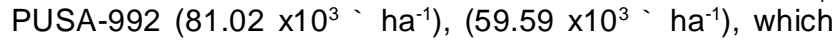
was significantly superior with others followed by $\mathrm{V}_{2}$ : ASJ$105\left(78.06 \times 10^{3}{ }^{\prime} \mathrm{ha}^{-1}\right)\left(54.34 \times 10^{3}{ }^{\prime} \mathrm{ha}^{-1}\right)$ and $\mathrm{V}_{5}$ : ICPL88039 recorded minimum seed yield $\left(56.83 \times 10^{3}\right.$ ' ha $\left.^{-1}\right)$ $\left(38.52 \times 10^{3}{ }^{-} \mathrm{ha}^{-1}\right)$, in both the years 2018 and 2019 respectively (Table 2).

\section{Net return}

It is the return from the seed after the deducted cost of cultivation. It is found high to low in different sowing dates, viz: $\mathrm{D}_{1}: 25^{\text {th }}$ May $\left(49.37 \times 10^{3} \mathrm{ha}^{-1}\right)$ and $\left(26.88 \times 10^{3^{\prime}} \mathrm{ha}^{-1}\right)$ to $\mathrm{D}_{4}: 10^{\text {th }}$ July $\left(32.66 \times 10^{3} \mathrm{ha}^{-1}\right)$ and $\left(13.96 \times 10^{3}{ }^{\prime} \mathrm{ha}^{-1}\right)$ in both the year 2018 and 2019 respectively. In respective of genotypes the highest net returns found in genotype $\mathrm{V}_{4}$ :

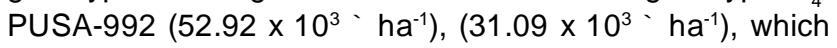
was significantly superior with others followed by $\mathrm{V}_{2}$ : ASJ$105\left(49.96 \times 10^{3}{ }^{\prime}\right.$ ha $\left.^{-1}\right)\left(25.84 \times 10^{3}{ }^{\prime} h^{-1}\right), V_{3}$ : Pant-291 $\left(40.06 \times 10^{3}{ }^{\prime}\right.$ ha $\left.^{-1}\right)\left(19.16 \times 10^{3}{ }^{\prime}\right.$ ha $\left.^{-1}\right)$ and $V_{5}$ : ICPL-88039 recorded lessnet returns (28.73 $\left.\times 10^{3}{ }^{`} \mathrm{ha}^{-1}\right)\left(10.02 \times 10^{3}{ }^{`} \mathrm{ha}^{-1}\right)$, in both the years respectively (Table 2 ).

\section{$B: C$ ratio}

It is the ratio between benefit to cost of cultivation of pigeonpea crop. B:C ratio is recorded higher in early planted/ sown conditions of redgram to less in late planted/sown conditions, viz: $D_{1}: 25^{\text {th }}$ May (1.76) and (1.69) to $D_{4}: 10^{\text {th }}$ July (1.16) and (1.05) in both the years respectively. In respective of genotypes the highest $B: C$ ratio found in genotype $\mathrm{V}_{4}$ : PUSA-992 (1.88), (1.89), which was significantly superior with others followed by $\mathrm{V}_{2}$ : ASJ-105 (1.78) (1.63) and $V_{5}$ : ICPL-88039 recorded less net returns (1.02) (0.86), in both the years respectively (Table 2). Similar results were reported by Kumar et al., (2008).

\section{Energy dynamics}

Different energy index and efficiency described inTable 3.

\section{Energy input}

It is the energy derives by different sources to cultivation viz: manpower, machine water, etc. were calculated and multiply with the equivalent unit (Table 1 ) in all treatment is workout is $\left(11.17 \times 10^{3} \mathrm{MJ} \mathrm{ha}^{-1}\right)$ and $\left(11.34 \times 10^{3} \mathrm{MJ} \mathrm{ha}^{-1}\right)$ in both the year respectively in all treatment same.

\section{Energy output ( $\times 10^{3} \mathrm{MJ} \mathrm{ha}^{-1}$ )}

It is energy output that includes energy produced in the form of seed and stover.In the sowing dates the energy output varies from $D_{1}: 25^{\text {th }}$ May $\left(109.45 \times 10^{3} \mathrm{MJ} \mathrm{ha}^{-1}\right)$ and 


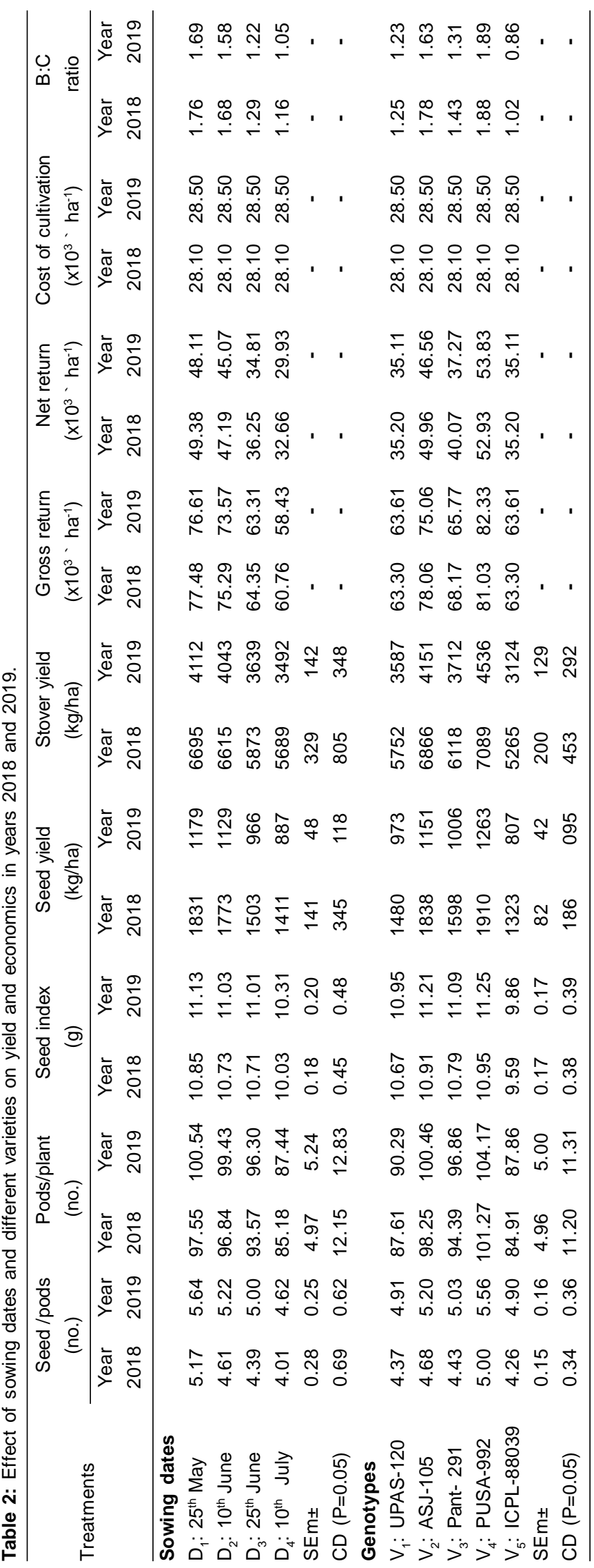


Energy and Economic Budgeting of Pigeonpea Genotypes (Cajanus cajan L.) at Various Sowing Dates

Table 3: Effect of sowing dates and different Varieties on energetic of pigeonpea years 2018 and 2019.

\begin{tabular}{|c|c|c|c|c|c|c|c|c|c|c|}
\hline \multirow{3}{*}{ Treatments } & \multicolumn{2}{|c|}{$\begin{array}{l}\text { Energy input } \\
\left(\times 10^{3} \mathrm{MJ} \mathrm{ha}^{-1}\right)\end{array}$} & \multicolumn{2}{|c|}{$\begin{array}{l}\text { Energy output } \\
\left(x 10^{3} \mathrm{MJ} \mathrm{ha}^{-1}\right)\end{array}$} & \multicolumn{2}{|c|}{$\begin{array}{l}\text { Energy balance } \\
\left(\times 10^{3} \mathrm{MJ} \mathrm{ha}^{-1}\right)\end{array}$} & \multicolumn{2}{|c|}{$\begin{array}{r}\text { Energy use } \\
\text { efficiency }\end{array}$} & \multicolumn{2}{|c|}{$\begin{array}{l}\text { Energy productivity } \\
\left(\mathrm{kg} \mathrm{MJ}^{-1}\right)\end{array}$} \\
\hline & Year & Year & Year & Year & Year & Year & Year & Year & Year & Year \\
\hline & 2018 & 2019 & 2018 & 2019 & 2018 & 2019 & 2018 & 2019 & 2018 & 2019 \\
\hline \multicolumn{11}{|l|}{ Sowing dates } \\
\hline $\mathrm{D}_{1}: 25^{\text {th }}$ May & 11.17 & 11.34 & 109.45 & 67.99 & 98.28 & 56.65 & 9.80 & 5.99 & 0.164 & 0.104 \\
\hline$D_{2}: 10^{\text {th }}$ June & 11.17 & 11.34 & 107.63 & 66.42 & 96.46 & 55.08 & 9.63 & 5.86 & 0.159 & 0.100 \\
\hline $\mathrm{D}_{3}: 25^{\text {th }}$ June & 11.17 & 11.34 & 94.56 & 59.08 & 83.39 & 47.74 & 8.46 & 5.21 & 0.135 & 0.085 \\
\hline$D_{4}: 10^{\text {th }}$ July & 11.17 & 11.34 & 90.97 & 56.13 & 79.79 & 44.79 & 8.14 & 4.95 & 0.126 & 0.078 \\
\hline \multicolumn{11}{|l|}{ Genotypes } \\
\hline$V_{1}:$ UPAS-120 & 11.17 & 11.34 & 92.72 & 58.53 & 81.55 & 47.18 & 8.30 & 5.16 & 0.132 & 0.086 \\
\hline$V_{2}:$ ASJ-105 & 11.17 & 11.34 & 111.69 & 68.08 & 100.51 & 56.74 & 10.00 & 6.00 & 0.164 & 0.101 \\
\hline $\mathrm{V}_{3}:$ Pant- 291 & 11.17 & 11.34 & 98.96 & 60.55 & 87.79 & 49.21 & 8.86 & 5.34 & 0.143 & 0.089 \\
\hline$V_{4}:$ PUSA-992 & 11.17 & 11.34 & 115.49 & 74.47 & 104.31 & 63.13 & 10.34 & 6.56 & 0.171 & 0.111 \\
\hline$V_{5}:$ ICPL-88039 & 11.17 & 11.34 & 84.43 & 50.40 & 73.25 & 39.06 & 7.56 & 4.44 & 0.118 & 0.071 \\
\hline
\end{tabular}

$\left(67.99 \times 10^{3} \mathrm{MJ} \mathrm{ha}^{-1}\right)$ to $\mathrm{D}_{4}: 10^{\text {th }}$ July $\left(90.97 \times 10^{3} \mathrm{MJ} \mathrm{ha}^{-1}\right)$ and $\left(56.13 \times 10^{3} \mathrm{MJ} \mathrm{ha}^{-1}\right)$ in both the year 2018 and 2019 respectively. Similar findings are the same by Mittal and Dhawan 1989. In respective of genotypes, the higher energy output found in genotype $\mathrm{V}_{4}$ : PUSA-992 $\left(115.49 \times 10^{3} \mathrm{MJ} \mathrm{ha}^{-1}\right)$, $\left(74.47 \times 10^{3} \mathrm{MJ} \mathrm{ha}^{-1}\right)$, which was superior with others followed by $\mathrm{V}_{2}$ : ASJ-105 $\left(111.69 \times 10^{3} \mathrm{MJ} \mathrm{ha}^{-1}\right)\left(68.08 \times 10^{3} \mathrm{MJ} \mathrm{ha}^{-1}\right)$ and $\mathrm{V}_{5}$ : ICPL-88039 recorded less energy output $\left(84.43 \times 10^{3}\right.$ $\left.\mathrm{MJ} \mathrm{ha}^{-1}\right)\left(50.40 \times 10^{3} \mathrm{MJ} \mathrm{ha}^{-1}\right)$, in both the year 2018 and 2019 respectively (Table 3 ). Similar research found by the Shilpha et al. (2018).

\section{Energy balance}

It is the balance between energy inputto energy output in the cultivation of pigeonpea. In the sowing dates the energy balance varies from $D_{1}: 25^{\text {th }}$ May $\left(98.28 \times 10^{3} \mathrm{MJ} \mathrm{ha}^{-1}\right)$ and $\left(56.65 \times 10^{3} \mathrm{MJ} \mathrm{ha}^{-1}\right)$ to $\mathrm{D}_{4}: 10^{\text {th }}$ July $\left(79.79 \times 10^{3} \mathrm{MJ} \mathrm{ha}^{-1}\right)$ and $\left(44.79 \times 10^{3} \mathrm{MJ} \mathrm{ha}^{-1}\right)$ in both the year 2018 and 2019 respectively. In respective of genotypes the higher energy balance found in genotype $\mathrm{V}_{4}$ : PUSA-992 $\left(104.31 \times 10^{3} \mathrm{MJ}\right.$ $\left.\mathrm{ha}^{-1}\right),\left(63.13 \times 10^{3} \mathrm{MJ} \mathrm{ha}^{-1}\right)$, which was superior with others followed by $\mathrm{V}_{2}$ : ASJ-105 $\left(100.51 \times 10^{3} \mathrm{MJ} \mathrm{ha}^{-1}\right)\left(56.74 \times 10^{3}\right.$ MJ ha' ${ }^{-1}$ ) and $\mathrm{V}_{5}$ : ICPL-88039 recorded less energy balance $\left(73.25 \times 10^{3} \mathrm{MJ}^{-1}\right)\left(39.06 \times 10^{3} \mathrm{MJ} \mathrm{ha}^{-1}\right)$, in both the year 2018 and 2019 respectively. (Table 3 ) similar results reported by Chaudhary et al., (2006).

\section{Energy use efficiency}

It is the ratio of energy output to energy input in the cultivation of pigeonpea. In the sowing dates, the energy use efficiency varies from $D_{1}: 25^{\text {th }}$ May $(9.80)$ and $(5.99)$ to $D_{4}: 10^{\text {th }}$ July (8.14) and (4.95) in both the years 2018 and 2019 respectively. In respective of genotypes the higher energy use efficiency found in genotype $V_{4}$ : PUSA-992 (10.34), (6.56), which was superior with others followed by $V_{2}$ : ASJ-105 (10.0) (6.0) and $V_{5}$ : ICPL-88039 recorded less energy use efficiency (7.56) (4.44), in both the years respectively. (Table 3 ). Similar results were found by Kumar et al. (2008).

\section{Energy productivity (kg $\mathbf{M J}^{-1}$ )}

It is the ratio of seed yield to energy input used in the cultivation of pigeonpea. In the sowing dates the energy productivity $\left(\mathrm{kg} \mathrm{MJ}^{-1}\right)$ varies from $\mathrm{D}_{1}: 25^{\text {th }}$ May $(0.164)$ and $(0.104)$ to $D_{4}: 10^{\text {th }}$ July $(0.126)$ and $(0.078)$ in both years respectively. In respective of genotypes the higher energy productivity found in genotype $\mathrm{V}_{4}$ : PUSA-992 (0.171), (0.111), which was superior with others followed by $V_{2}$ : ASJ105 (0.164) (0.101) and $V_{5}$ : ICPL-88039 recorded less energy productivity (0.118) (0.071), in both the year 2018 and 2019 respectively (Table 3 ). Similar results were found by Chaudhary et al.(2006).

\section{CONCLUSION}

For the NWPZ zone of Rajasthan, based on two years of fixed land experimentation, it was revealed that the first fortnight of June suitable for the sowing of pigeonpea for good harvesting of seed yield. The most promising genotypes PUSA-992 are found economically in terms of production and profitability.

\section{REFERENCES}

Chaudhary, V., Gangwar, B. and Pandey, D. (2006). Auditing of energy use and output of different cropping systems in India. Agricultural Engineering International: The CIGR Ejournal. Manuscript EE 05. 8, 1-13.

Gomez, K.A. and Gomez, A.A. (1984). Statistical Procedures for Agricultural Research. John Willley and Sons, NY.

Kumar, N., Gopinath, K.A., Srivastva, A.K. and Mahajan, V. (2008). Performance of pigeon pea [Cajanus cajan (L.) Millsp.] at different sowing dates in the mid-hills of Indian Himalaya, Archives of Agronomy and Soil Science. 54(5): 507-514.

Mittal, J.P. and Dhawan, K.C. (1989). Energy parameters for raising crops under various irrigation treatments in Indian agriculture. Agriculture, Ecosystems and Environment. 25(1): 1125. 
Ram, H., Singh, G., Sekhon, H.S. and Khanna, V. (2011). Effect of sowing time on the performance of pigeonpea genotypes. Journal of Food Legumes. 24(3): 207-210.

Sarkar, S., Panda, S., Yadav, K.K. and Kandasamy, P. (2020). Pigeonpea (Cajanus cajan) an important food legume in Indian scenario- A review. Legume Research. 43(5): 601-610.

Shilpha, S.M., Soumya, T.M., Mamathashree, C.M. and Girijesh, G.K. (2018). Energetics in various cropping systems. International Journal of Pure and Applied Bioscience. 6(4): 303-323.
Singh, G., Kaur, H. Aggarwal, N., Hari Ram, Gill, K. K. and Khanna, V. (2016). Symbiotic characters, thermal requirement, growth, yield and economics of pigeonpea (Cajanus cajan) genotypes sown at different dates under Punjab conditions. Journal of Applied and Natural Science. 8(1): 381-385.

Umesh, M.R., Shankar, M.A. and Ananda, N. (2013). Yield, nutrient uptake and economics of pigeonpea (Cajanus cajan L.) genotypes under nutrient supply levels in dryland alfisols of Karnataka. Indian Journal of Agronomy. 58(4): 554-559. 